Original Research Paper

\title{
Status of Air Quality with Potential Linkage to the Metrological Conditions in Three Major Cities of Pakistan
}

\author{
${ }^{1,2}$ Naima Hamid, ${ }^{1,2}$ Muhammad Junaid, ${ }^{3}$ Syeda Maria Ali, ${ }^{4}$ Maida Zahid and ${ }^{1}$ De-Sheng Pei \\ ${ }^{1}$ Key Laboratory of Reservoir Aquatic Environment, Chongqing Institute of Green and Intelligent Technology, \\ Chinese Academy of Sciences, Chongqing 400714, China \\ ${ }^{2}$ University of Chinese Academy of Sciences, Beijing 100049, China \\ ${ }^{3}$ Department of Environmental Sciences, Female Campus, International Islamic University Islamabad, Pakistan \\ ${ }^{4}$ Research and Development Division, Pakistan Meteorological Department, Islamabad, Pakistan
}

Article history

Received: 26-01-2019

Revised: 7-02-2019

Accepted: 09-03-2019

Corresponding Author: De-Sheng Pei

Key Laboratory of Reservoir Aquatic Environment,

Chongqing Institute of Green and Intelligent Technology, Chinese Academy of Sciences, Chongqing 400714, China Email: peids@cigit.ac.cn

\begin{abstract}
Environmental pollution being fatal for all living organisms is growing adversely due to excessive industrialization and urbanization. Vehicular emissions have aggravated the situation and pose detrimental effects on human health. In this study, the trend of ambient air quality was analyzed in the three metropolitan cities of Pakistan, including Karachi, Lahore and Islamabad for a period of three years (2008-2010). Air pollutants, such as $\mathrm{NO}, \mathrm{NO}_{\mathrm{x}}, \mathrm{NO}_{2}$ and $\mathrm{PM}_{2.5}$ were recorded usingmobile air quality monitoring stations in the target areas. Results from statistical analysis revealed $\mathrm{PM}_{2.5}$ with highest levels in all the cities, albeit exceeded the World Health Organization (WHO) guideline limits. Spearman correlation revealed that the levels of air pollutants were negatively correlated with the temperature and rainfall, whereas positively correlated with the wind speed. Annual and seasonal variations in the concentrations of the air pollutants was also observed and the highest concentration was recorded in Karachi during the winter season that could be attributed to inversion phenomenon. In addition, the elevated vehicular emissions were observed in Lahore, implied comparatively high air pollution loads, comparison to those of Karachi and Islamabad. The widespread use of low-quality fuel, coupled with a dramatic expansion in the number of vehicles has led to significant air pollution problems, especially in Lahore and Karachi. Therefore, the efficient mass transit system and urban forests should be introduced to abate the ever-increasing levels of organic pollutants and improve the state of ambient air quality in the major cities of Pakistan.
\end{abstract}

Keywords: Ambient Air Quality Emission Concentrations, Meteorological Parameters, Vehicular Emissions

\section{Introduction}

Urban air pollution is rapidly becoming an environmental problem of public concern worldwide. Urbanization and industrialization with an unsustainable use of resources aggravates the problem (Guo et al., 2017; Parekh et al., 2001). Anthropogenic particles are emitted directly into the atmosphere from combustion and industrial processes in the urban areas that contributes to the drastic rise in air pollution (Di et al., 2017a; 2017b; Katsouyanni et al., 1993). Urban air pollution has serious implications for human health and well-being, as well as for the whole environment (Aunan and Pan, 2004; Li et al., 2018). According to the World Health Organization (WHO), two third of the deaths in year 2000 were caused by exposure to urban air pollution in developing countries of Asia (Ali and Athar, 2010; WHO/UNEP, 1992). A number of air pollution catastrophes occurred in industrial countries between 1950s and 1970s, such as the London smog of 1952, however, air quality in western countries has significantly improved since the 1970s (Cai et al., 2017; McCarroll and Bradley, 1996; Wing et al., 2017).

Meteorology plays a crucial role in ambient distributions of air pollution (Dentener et al., 2006; Hou and $\mathrm{Wu}, 2016$; Srivastava, 2006). In fact, there is a strong seasonality in meteorological variables that modulate air quality levels (Espinosa et al., 2004; Karar 
et al., 2005). Wind is a key meteorological variable having a major impact on horizontal transport and distribution of air pollutants, as well as vertical mixing and dispersion in a region (Xie et al., 2018). Downwind areas from proximate emission sources, such as industrial locations and highways exhibited the significantly higher levels of air pollutants ( $\mathrm{Li}$ et al., 2010). Traffic emissions are known to be responsible for a substantial share of urban air pollution, such as nitrogen dioxide $\left(\mathrm{NO}_{2}\right)$, carbon monoxide and particulate matters (Deng et al., 2018). In recent years, the aerosol problem has become increasingly acute due to increased loadings of atmospheric pollutants in Asian countries with monsoonal climates, such as India and China (Christodoulakis et al., 2018, Srivastava, 2006, Tsang, 2008; Zhang et al., 2008).

Air pollution is an emerging environmental issue and is considered to be a critical urban problem in major cities of Pakistan (Shahid et al., 2016). The thickly populated urban areas are more vulnerable to the negative impacts of vehicular emissions due to congestion of vehicles, which has heavily affected quality of life (Cai et al., 2017; Zhang et al., 2008). Moreover, the air pollutants can change the atmosphere compositions through chemical reaction and bring about the long-term climate change impacts (Ilyas et al., 2010; Khreis et al., 2017). Present study estimated the status of ambient air quality in three metropolitan cities of Pakistan (Islamabad, Lahore and Karachi) for three years. Correlation analysis was also run between the levels air pollutants $\left(\mathrm{NO}, \mathrm{NO}_{\mathrm{x}}, \mathrm{NO}_{2}\right.$ and $\mathrm{PM}_{2.5}$ ) and meteorological parameters (Minimum temperature, maximum temperature, precipitation, wind speed), using annual and seasonal based to unveil the driving factors of deteriorating ambient air quality in major cities of Pakistan. This study depicts the trends of emissions, associated adverse effects, also defines the role of meteorological parameters as driving factors of air emissions. The statistical findings from this study can be used for urban town planning to adopt appropriate measures to minimize the hazardous effects of the exposure and dispersion of air emissions.

\section{Materials and Methods}

\section{Site Description}

The study is focused on three cities, i.e., Islamabad (Lat: $33^{\circ} \quad 40^{\prime} \mathrm{N}$ and Long: $72^{\circ} 30^{\prime} \mathrm{E}$ ), Lahore (Lat: $31^{\circ}$ $32 ' \mathrm{~N}$; Long: $74^{\circ} 22^{\prime} \mathrm{E}$ ) and Karachi (Lat: $24^{\circ} 51^{\prime} \mathrm{N}$; Long: $67^{\circ} 02^{\prime} \mathrm{E}$ ) (Fig. 1). The climate of Islamabad, Karachi and Lahore is usually humid subtropical/arid with extremely hot summers and dry winters.

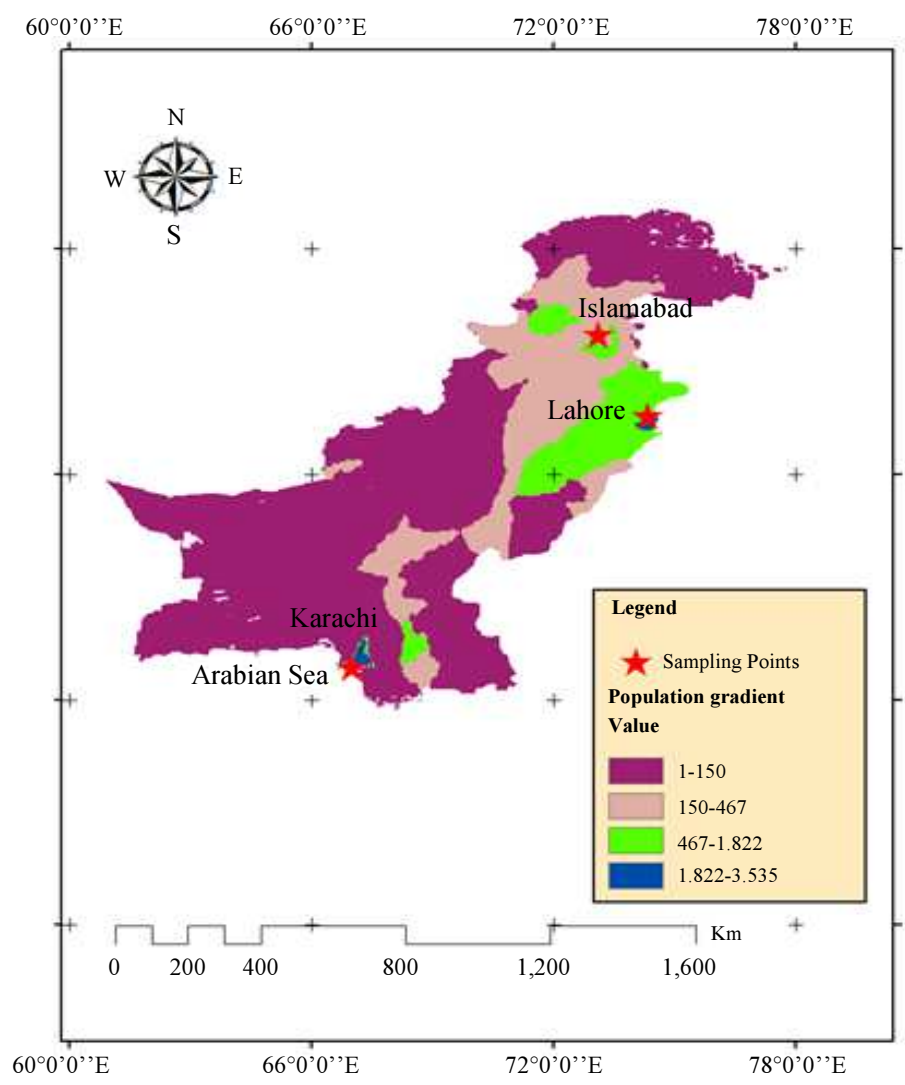

Fig. 1: Map of locations of cities used in study 
The temperature ranges $36-38^{\circ} \mathrm{C}$ in Islamabad and 36 $46^{\circ} \mathrm{C}$ in Lahore during summer. The Karachi lies on the flat, sandy coast facing the Arabian Sea just north of the Indus River delta. There fore, the temperature ranges from 30 to $44^{\circ} \mathrm{C}$ during summer season (Apr-Aug) and 12 to $25^{\circ} \mathrm{C}$ during winter season (Dec-Feb).

\subsection{Data and Analysis}

The monthly mean available emission data $(\mathrm{NO}$, $\mathrm{NO}_{\mathrm{x}}, \mathrm{NO}_{2}$ and $\mathrm{PM}_{2.5}$ ) was acquired in 2014 from Pakistan Environmental Protection Agency (Pak-EPA) for three cities (Islamabad, Lahore and Karachi) for the years (2008-2010). It was a collaborative project initiated between Pak-EPA and Japan International Cooperation Agency (JICA). The first preliminary active air sampling for the metropolitan cities was completed in 2010. The air quality sampling was conducted using a mobile station that measures hourly concentrations of air emissions. The meteorological data (minimum temperature, maximum temperature, rainfall and wind speed) was acquired from data archives of Pakistan Meteorological Department (PMD). The data were analyzed using Microsoft Excel 2010 and SPSS version 20 (IBM, USA). Arc GIS version 9.3 (ESRI, USA) was used to draw site maps. The annual and seasonal trends of emissions have been investigated forthree cities. Pakistan has four well marked seasons winter (Dec-Mar), spring (Apr-May), summer (Jun-Sep) and autumn (Oct-Nov). These seasons has been considered for the seasonal analysis in the study. Then the relationship between meteorological parameters and emission concentration has been determined. The basic statistics (mean, minimum, maximum, variance, standard deviation) for the meteorological parameters and for the emissions has also been observed. Non- parametric correlation was used to explain the significance of meteorological parameters influencing the emissions transport.

\section{Results and Discussion}

\subsection{Annual Trends of Emissions and Relationship with Meteorological Parameters 2008-10}

The annual trends for the air pollutants $\left(\mathrm{NO}, \mathrm{NO}_{2}\right.$, $\mathrm{NO}_{\mathrm{x}}$ and $\mathrm{PM}_{2.5}$ ) were observed in Islamabad, Lahore Karachi for three consecutive years (2008-2010). The annual mean concentration of pollutants like $\mathrm{NO}_{\mathrm{x}}$ and NO was observed high in Islamabad. However, the high levels of $\mathrm{NO}_{2}$ and $\mathrm{PM}_{2.5}$ has been noticed in Lahore as shown in (Fig. 2). This could be due to the aggravated vehicular emissions (diesel and gasoline driven) and the biomass combustion in the metropolitan area. The comparative plots have been drawn between meteorological parameters and the emission concentration, which showed the annual mean minimum, maximum and rainfall on primary axis and emission concentration on secondary axis. The annual mean concentration of $\mathrm{NO}_{\mathrm{x}}$ was reported at $75.86 \mathrm{ppb}$ and $58.33 \mathrm{ppb}$ respectively in Islamabad and Karachi while that of NO observed at $69.84 \mu \mathrm{g} / \mathrm{m}^{3}$ and $38.47 \mu \mathrm{g} / \mathrm{m}^{3}$ In case of Lahore, the concentrations $\mathrm{NO}_{\mathrm{x}}$ and $\mathrm{NO}$ were observed lower, i.e., $47.06 \mathrm{ppb}$ and $26.77 \mu \mathrm{g} / \mathrm{m}^{3}$, respectively. The mean annual peak concentrations for $\mathrm{PM}_{2.5}$ and $\mathrm{NO}_{2}$ was observed in Lahore with a value of $116.4 \mu \mathrm{g} / \mathrm{m}^{3}$ and 51.50 $\mu \mathrm{g} / \mathrm{m}^{3}$ and decreases in Islamabad $\left(67.37 \mu \mathrm{g} / \mathrm{m}^{3}\right.$ and 66.54 $\left.\mu \mathrm{g} / \mathrm{m}^{3}\right)$ and Karachi $\left(43.93 \mu \mathrm{g} / \mathrm{m}^{3}\right.$ and $49.06 \mu \mathrm{g} / \mathrm{m}^{3}$ ) (Fig. 2). The main reason was due to the high traffic load with an increase in minimum temperature, aggravating the situation. According to Pak- EPA, the ambient quality standards for an annual average value of $\mathrm{PM}_{2.5}$ acceptable up to $25 \mu \mathrm{g} / \mathrm{m}^{3}$.

The results for statistical analysis of data for all the variables are shown in Table 1. Amongst all the emissions, $\mathrm{PM}_{2.5}$ concentrations were the highest with a mean value of $127.6 \mu \mathrm{g} / \mathrm{m}^{3}$ in 2009 . NO is derived from nitrogen $\left(\mathrm{N}_{2}\right)$ in high-temperature combustion processes, such as internal combustion engines and $\mathrm{NO}_{\mathrm{x}}$ emissions released from these engines contain over $90 \%$ of $\mathrm{NO}$, which is relatively unstable, compared to oxygen $\left(\mathrm{O}_{2}\right)$ and $\mathrm{N}_{2}$ (Dotse et al., 2016; Liu et al., 2018). The main fate of $\mathrm{NO}$ is to convert into $\mathrm{NO}_{2}$ after reaction with ozone $\left(\mathrm{O}_{3}\right)$ in the ambient atmosphere (Derwent and Hertel, 1998; Vedrenne et al., 2016). $\mathrm{NO}_{\mathrm{x}}$ and $\mathrm{NO}$ are the secondary pollutants that require another reactant to change their form, therefore, the concentrations of these pollutants were lower, compared to that of $\mathrm{PM}_{2.5}$ and $\mathrm{NO}_{2}$ (Zawacki et al., 2018). $\mathrm{PM}_{2.5}$ and $\mathrm{NO}_{2}$ are the primary pollutants emitted from the vehicular emissions and industrial activities, which implied the peak emission values in Lahore city during the study years. The maximum rainfall has been observed in Islamabad city with an average value of $81.1 \mathrm{~mm}$, as compared to Lahore and Karachi. It has also been noticed that the influence of rainfall is quite obvious on suspended particulate matter $\left(\mathrm{PM}_{2.5}\right)$ as compared to other pollutants $(\mathrm{NO}$, $\mathrm{NO}_{2}, \mathrm{NO}_{\mathrm{x}}$ ) in the atmosphere. The concentration of $\mathrm{PM}_{2.5}$ drops with the increase in amount of rainfall most probably due to the wetness and the weight of suspended particulates increases and they are settle down on the ground (Hou and $\mathrm{Wu}, 2016$ ). As far as $\mathrm{NO}, \mathrm{NO}_{2}$ and $\mathrm{NO}_{\mathrm{x}}$ are concerned, they are gaseous pollutants already a part of the atmosphere. Temperature has great influence on pollution in the atmosphere (Chen et al., 2018). Both minimum and maximum temperature showed a negative correlation with the emission concentrations. When the temperature is high, there are turbulent flows and dramatic convective motions and the atmosphere is unstable (Deng et al., 2018). On contrary, when the temperature is low, the atmosphere is so stable that the pollution concentration becomes high (Zhao and Shi, 2012). 


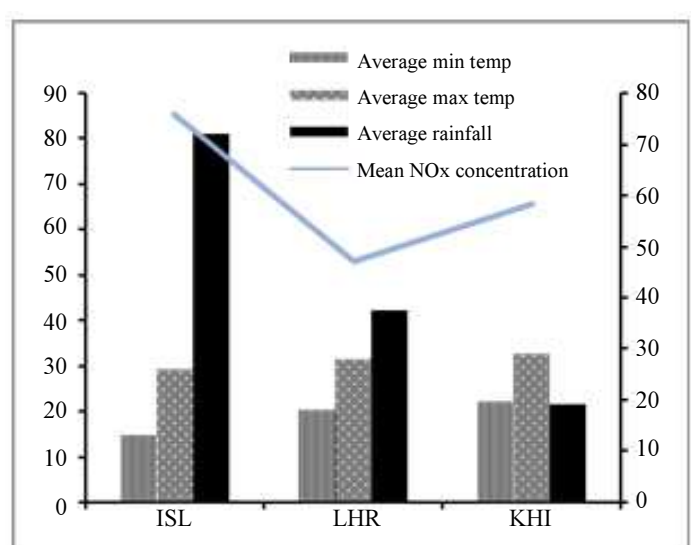

(a)

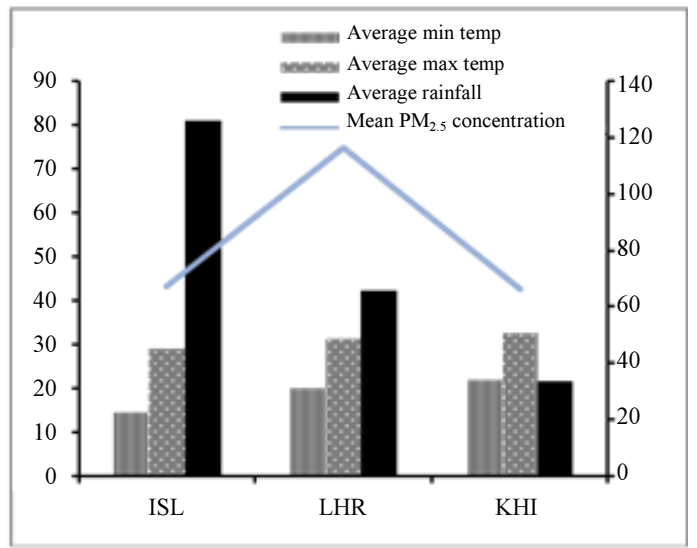

(c)

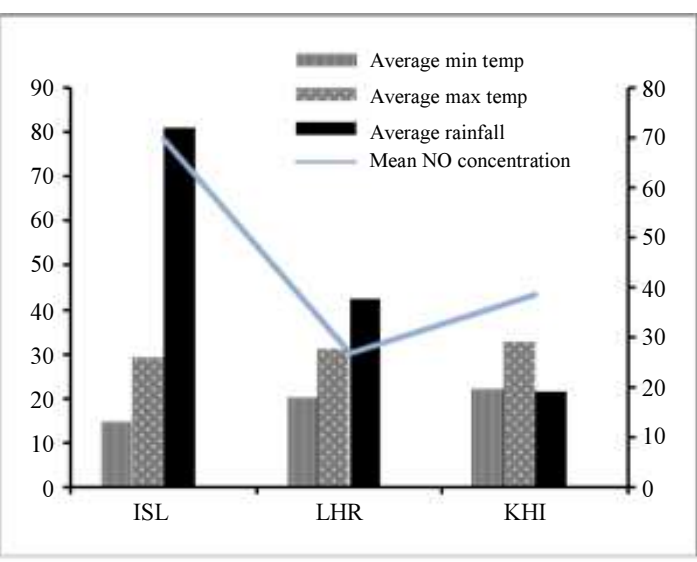

(b)

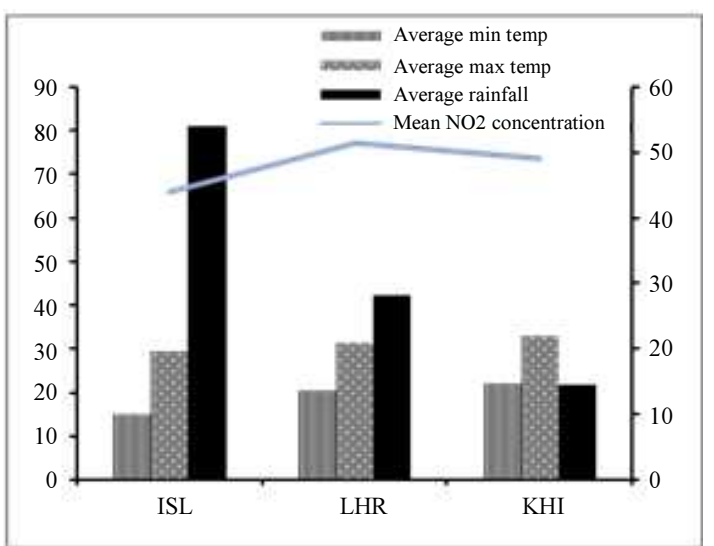

(d)

Fig. 2: Annual mean variation of (a) NOx (ppb) emissions (b) $\mathrm{NO}\left(\mu \mathrm{g} / \mathrm{m}^{3}\right)$ emissions (c) $\mathrm{NO}_{2}\left(\mu \mathrm{g} / \mathrm{m}^{3}\right)$ emissions and (d) $\mathrm{PM}_{2.5}$ ( $\mu \mathrm{g} / \mathrm{m}^{3}$ ) emissions with meteorological parameters from 2008-2010. Primary y-axis all metrological parameters (minimum temperature $\left({ }^{\circ} \mathrm{C}\right.$ ), maximum temperature $\left({ }^{\circ} \mathrm{C}\right)$ and rainfall $(\mathrm{mm})$ were presented, on secondary y-axis all the emission concentrations are presented

Table 1: Mean, Min-Max value, Variance and SD of Climatic variables (Minimum temperature, Maximum temperature, Rainfall and Wind speed) for Islamabad, Lahore and Karachi cities

\begin{tabular}{|c|c|c|c|c|c|c|c|c|c|c|c|c|}
\hline \multirow[b]{2}{*}{ Islamabad } & \multicolumn{4}{|l|}{2008} & \multicolumn{4}{|l|}{2009} & \multicolumn{4}{|l|}{2010} \\
\hline & Mean & Min-Max & Variance & SD & Mean & Min-Max & Variance & SD & Mean & Min-Max & Variance & SD \\
\hline Min Temp $\left({ }^{\circ} \mathrm{C}\right)$ & 28.4 & $14.8-26.4$ & 52.2 & 7.23 & 29.33 & $19.2-36.9$ & 42.68 & 6.53 & 29.89 & $21.16-37.2$ & 35.29 & 5.94 \\
\hline Max Temp $\left({ }^{\circ} \mathrm{C}\right)$ & 15.3 & $1.79-24.8$ & 72.3 & 8.5 & 13.99 & $2.5-23.8$ & 55 & 7.42 & 14.7 & $1.49-24.0$ & 65.17 & 8.07 \\
\hline Rainfall (mm) & 109 & $4.0-353$ & 13866 & 117.76 & 48.83 & $0.4-178.3$ & 2435 & 49.35 & 85.01 & $0-225.8$ & 7487.99 & 86.53 \\
\hline $\mathrm{NO}\left(\mu \mathrm{g} / \mathrm{m}^{3}\right)$ & 62.6 & $5.13-166$ & 3078.9 & 55.49 & 67.78 & $8.9-167.1$ & 2338.1 & 48.35 & 79.1 & $7.2-189.3$ & 3909.4 & 62.53 \\
\hline $\mathrm{NO} 2\left(\mu \mathrm{g} / \mathrm{m}^{3}\right)$ & 41.7 & $12.7-99.1$ & 842.45 & 29.03 & 48.72 & $28.4-68.5$ & 154.6 & 12.44 & 41.32 & $20.2-66.2$ & 195.85 & 13.99 \\
\hline NOx (ppb) & 67.4 & $10.7-162$ & 2589.2 & 50.88 & 77.53 & $22-154.2$ & 1712.7 & 41.39 & 82.61 & $17.9-175.6$ & 2867.71 & 53.55 \\
\hline $\begin{array}{l}\text { PM2.5 }\left(\mu \mathrm{g} / \mathrm{m}^{3}\right) \\
\text { Lahore }\end{array}$ & 75 & $11.2-105$ & 872.1 & 29.53 & 59.28 & $21.8-111.8$ & 1126.7 & 33.57 & 67.84 & $27.8-125.9$ & 960.97 & 31 \\
\hline Min Temp $\left({ }^{\circ} \mathrm{C}\right)$ & 30.2 & $17.87-37.28$ & 38.72 & 6.22 & 32.75 & $20.0-43.56$ & 51.2 & 7.16 & 30.79 & $17.27-39.69$ & 49.26 & 7.02 \\
\hline Max Temp $\left({ }^{\circ} \mathrm{C}\right)$ & 19.77 & $6.96-27.69$ & 53.17 & 7.29 & 19.93 & $9.32-27.72$ & 50.4 & 7.1 & 20.87 & $7.80-27.78$ & 52.04 & 7.21 \\
\hline Rainfall (mm) & 51.41 & $0-283.1$ & 6255.1 & 79.09 & 31.29 & $0.1-111.6$ & 1302.7 & 36.09 & 44.13 & $0-296$ & 7761.9 & 88.1 \\
\hline $\mathrm{NO}\left(\mu \mathrm{g} / \mathrm{m}^{3}\right)$ & 19.81 & $1.77-65.87$ & 400.82 & 55.49 & 9.15 & $20.02-43.56$ & 167.53 & 12.94 & 51.36 & $0.4-170.2$ & 2526.92 & 50.27 \\
\hline $\mathrm{NO} 2\left(\mu \mathrm{g} / \mathrm{m}^{3}\right)$ & 40.64 & $13.8-70.5$ & 351.49 & 29.03 & 54.19 & $22.7-84.0$ & 406.5 & 20.16 & 59.71 & $25.3-92.1$ & 393.51 & 19.84 \\
\hline NOx (ppb) & 36.57 & $8.71-86.6$ & 578.2 & 50.88 & 36.41 & $13.2-64.4$ & 336.1 & 18.33 & 68.23 & $13.6-162.1$ & 2018.3 & 44.93 \\
\hline $\begin{array}{l}\text { PM2.5 }\left(\mu \mathrm{g} / \mathrm{m}^{3}\right) \\
\text { Karachi }\end{array}$ & 116.48 & $33.5-231.1$ & 2946.3 & 29.53 & 127.63 & $45.6-499.7$ & 15367.5 & 123.97 & 105.12 & $43.9-205$ & 2510.7 & 50.11 \\
\hline Min Temp $\left({ }^{\circ} \mathrm{C}\right)$ & 32.04 & $23.77-35.47$ & 14.26 & 3.78 & 32.94 & $26.2-36.8$ & 10.66 & 3.26 & 33.06 & $27.5-36.51$ & 9.73 & 3.12 \\
\hline Max Temp $\left({ }^{\circ} \mathrm{C}\right)$ & 21.9 & $11.14-28.98$ & 37.96 & 6.16 & 22.31 & $13.9-28.7$ & 31.09 & 5.58 & 21.95 & $11.5-28.53$ & 41.62 & 6.45 \\
\hline Rainfall (mm) & 10.27 & $0-54.5$ & 333.79 & 18.27 & 23.47 & $0-160.5$ & 2351.5 & 48.49 & 31.17 & $0-120.7$ & 2432 & 49.32 \\
\hline $\mathrm{NO}\left(\mu \mathrm{g} / \mathrm{m}^{3}\right)$ & 34.76 & $9.66-78.41$ & 458.75 & 21.42 & 39.46 & $14.6-80.1$ & 431.5 & 20.77 & 41.2 & $6.5-94.1$ & 1108.2 & 33.29 \\
\hline $\mathrm{NO} 2\left(\mu \mathrm{g} / \mathrm{m}^{3}\right)$ & 45.22 & $13.09-75.39$ & 521.87 & 22.84 & 54.84 & $29.0-95.31$ & 457.13 & 21.38 & 47.15 & $20.9-90.8$ & 432.9 & 20.81 \\
\hline NOx $(\mathrm{ppb})$ & 57.48 & $14.59-105.4$ & 1187.95 & 34.47 & 60.1 & $33.26-113.7$ & 713.12 & 26.7 & 57.43 & $16.1-121.7$ & 1198.3 & 34.62 \\
\hline $\operatorname{PM} 2.5\left(\mu \mathrm{g} / \mathrm{m}^{3}\right)$ & 71.85 & $34.5-123.5$ & 757.65 & 27.53 & 60.86 & $24.2-115.5$ & 1138 & 33.73 & 66.93 & $22.5-180.9$ & 2474.6 & 49.75 \\
\hline
\end{tabular}




\section{Seasonal Trends of Emissions and Relationship with Meteorological Parameters 2008-10}

Seasonal variations in weather have a considerable impact on the levels of pollutants in the atmosphere. Temperature showed the typical seasonal behavior with low values during the summer and high values during the winter (Yang et al., 2015). The analysis of seasonal variations of emissions revealed decrease in the level of air pollutants with the increase in the temperature. For Islamabad city, it was noted that in winter season there is a gradual rise in the concentration of pollutants, among all the concentration of $\mathrm{NO}_{\mathrm{x}}$ was recorded highest in winter 2009, with a value of $105.99 \mathrm{ppb}$, whereas in winter 2010 , showed the highest value $\left(133.2 \mu \mathrm{g} / \mathrm{m}^{3}\right)$ of NO concentration. This could be ascribed that in summer season pollutants move upwards due to higher atmospheric turbulence, while in winters air near the earth surface is cooler so the atmospheric turbulence is lower, responsible for lower dispersion of pollutants (Qiu et al., 2018). In the year 2008, $\mathrm{PM}_{2.5}$ showed the highest concentration $\left(94.58 \mu \mathrm{g} / \mathrm{m}^{3}\right)$ in spring season, compared to other years. In spring 2009, the value (44.97 $\mathrm{ppb})$ of $\mathrm{NO}_{\mathrm{x}}$ was quite high likewise same trend was observed for $\mathrm{NO}$ emission. In summer season with the rise in temperature the levels of emissions were decreased (Ilyas et al., 2010). Thus, maximum temperature is considered as a pollutant control parameter (Kartal, 1998; Xie et al., 2018). Similarly, in autumn season, a gradual increase has been recorded in emissions concentration. Highest concentration of NO $\left(115.6 \mathrm{ug} / \mathrm{m}^{3}\right)$ was observed in 2010 whereas $\mathrm{PM}_{2.5}$ showed its maximum concentration $\left(83.09 \mathrm{ug} / \mathrm{m}^{3}\right)$ in autumn 2009 (Fig. 3a).

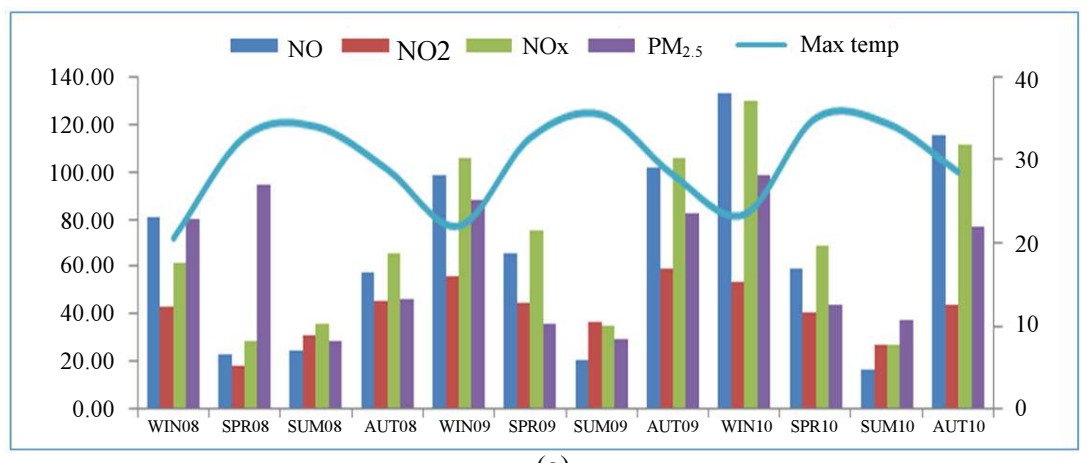

(a)

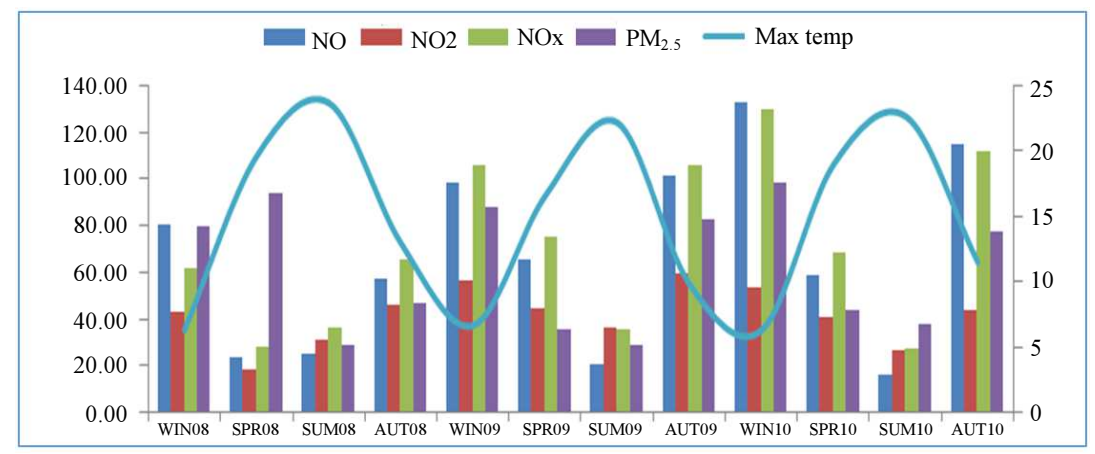

(b)

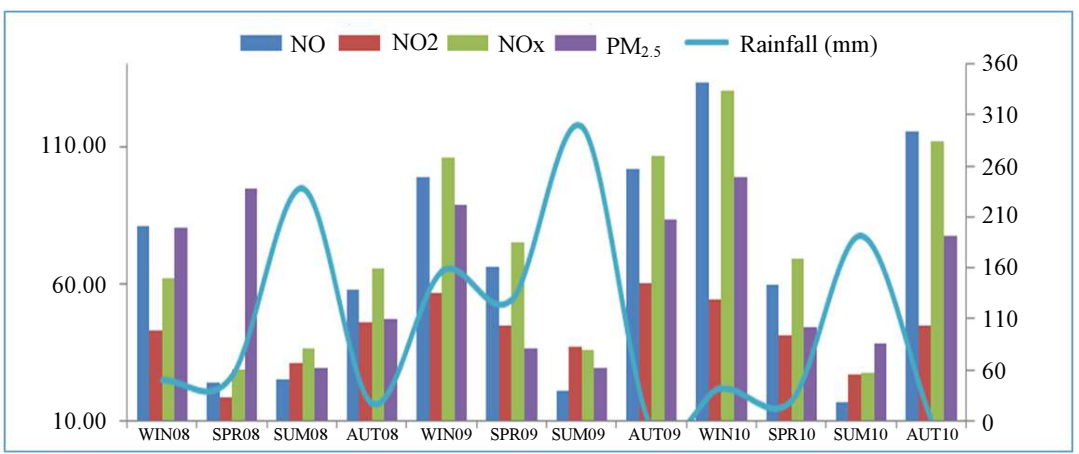

(c) 


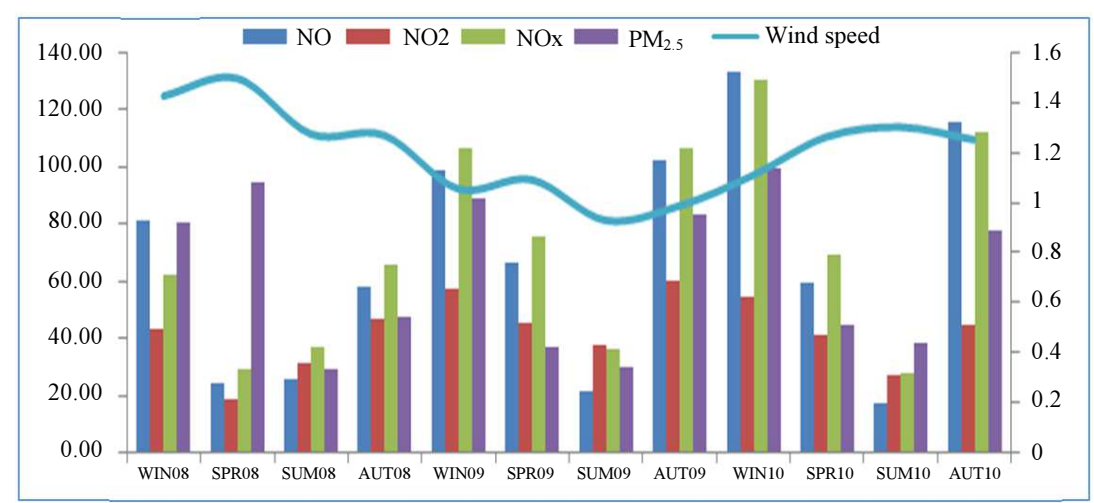

(d)

Fig. 3: Seasonal mean variation of emissions with (a) Maximum Temp $\left({ }^{\circ} \mathrm{C}\right)$ (b) Minimum Temp $\left({ }^{\circ} \mathrm{C}\right)(\mathrm{c})$ Rainfall (mm) and (d) Wind Speed $(\mathrm{m} / \mathrm{s})$ for Islamabad City

Similar trend with minimum temperature has been observed in Islamabad city, which showed a decrease with increase in level of pollutants. In winter 2010, NO $\left(133.2 \mathrm{ug} / \mathrm{m}^{3}\right)$ showed maximum value, whereas in spring 2008, $\mathrm{PM}_{2.5}\left(94.58 \mathrm{ug} / \mathrm{m}^{3}\right)$ revealed highest values. Due to increase in temperature, negligible amount of pollutants has been observed in all summer seasons (Xie et al., 2018; Zhao et al., 2015). Likewise, as the minimum temperature drops in autumn. Similarly, an increase in emissions was observed (Qiu et al., 2018). NO with a value of $115.6 \mathrm{ug} / \mathrm{m}^{3}$ showed its highest concentration in autumn 2010 whereas $\mathrm{NO}_{2}$ showed its maximum value $\left(59.87 \mathrm{ug} / \mathrm{m}^{3}\right)$ in autumn 2009 respectively (Fig. 3b). The safe level of long-term exposure to $\mathrm{NO}_{2}$ is set by World Health Organization (WHO) at $40 \mu \mathrm{g} / \mathrm{m}^{3}$ for 1 year monitoring, while for short-term monitoring (1 hour), the threshold is set at $200 \mu \mathrm{g} / \mathrm{m}^{3}$ (WHO/UNEP, 1992).

Negative correlation with rainfall was observed during the study years in Islamabad city. As the rainfall increased, the decrease in emissions was recorded. In winter 2010, the concentration of NO $\left(133.2 \mathrm{ug} / \mathrm{m}^{3}\right)$ and $\mathrm{NO}_{\mathrm{x}}(129.9 \mathrm{ppb})$ was the highest. In spring 2008, $\mathrm{PM}_{2.5}$ showed its maximum value $\left(94.58 \mathrm{ug} / \mathrm{m}^{3}\right)$, compared to other studied years. Likewise, in summer 2009 the lowest concentration of $\mathrm{PM}_{2.5}\left(29.51 \mathrm{ug} / \mathrm{m}^{3}\right)$ was observed with the increase in rainfall. The main reason of the lowest concentration of particulate matters in the monsoon can be attributed to the scavenging of particulate pollutants from the atmosphere due to rainfall (Stern, 1976; Xie et al., 2018). In autumn 2010, the maximum concentration of $\mathrm{NO}$ with a value of $115.6 \mathrm{ug} / \mathrm{m}^{3}$ was found in comparison to other years (Fig. 3c). Positive correlation with rainfall was observed during the study years. As the wind speed increased, the amount of pollutants was also increased. In winter 2010 , the maximum wind speed was recorded with a value of $1.07 \mathrm{~m} / \mathrm{sec}$.
Similarly, in same year the highest concentration of NO (133.2 ug/ $\mathrm{m}^{3}$ ) was observed (Fig. 3d).

For Lahore city, general trend showed a negative correlation of emissions with both maximum and minimum temperature. Among all the pollutants, $\mathrm{PM}_{2.5}$ concentrations were the highest and observed in autumn 2009 with a value of $366.8 \mathrm{ug} / \mathrm{m}^{3}$. WHO guidelines limit for 24-hour monitoring for $\mathrm{PM}_{2.5}$ is set at $50 \mu \mathrm{g} / \mathrm{m}^{3}$ that is quite high from the set limits and detrimental for health (Fig. 4a, b). As the rainfall increased, the decrease in the emissions concentration was recorded. In summer 2009, the rainfall was recorded as $249.3 \mathrm{~mm}$ and the emissions concentration was below the threshold limits. Similarly, in autumn 2009, as the rainfall decreased the level of pollutants particularly $\mathrm{PM}_{2.5}$ with a value was increased to $366.87 \mathrm{ug} / \mathrm{m}^{3}$ (Fig. $4 \mathrm{c}$ ). Temperature showed an inverse relation with most of the pollutants because of the role of the heat in warming up the surface of the earth by the incoming radiation that strike the earth and warms it, thus making the surface air warmer and consequently reducing its density, so it expands and goes upward to be replaced by cold air and so on. This process increases the amounts of the up going air currents (Deng et al., 2018; Ilyas et al., 2010). When the horizontal and vertical air mixing processes increase, they reduce the concentration of the pollutants in it. Wind speed showed positive correlation with emission concentrations (Deng et al., 2018; Guo et al., 1999). In Autumn 2009, $\mathrm{PM}_{2.5}\left(366.87 \mathrm{ug} / \mathrm{m}^{3}\right)$ maximum concentration was recorded with an increase in wind speed with a value of $1.21 \mathrm{~m} / \mathrm{sec}$ (Fig. $4 \mathrm{~d}$ ).

For Karachi city, pollutant emissions showed a negative correlation with maximum temperature throughout the study period. As in winter season when the temperature drops increase in the level of pollutants has been observed (Qiu et al., 2018). But if we compare the general trend of pollutants in winter, spring and summer season a decrease has been recorded. 


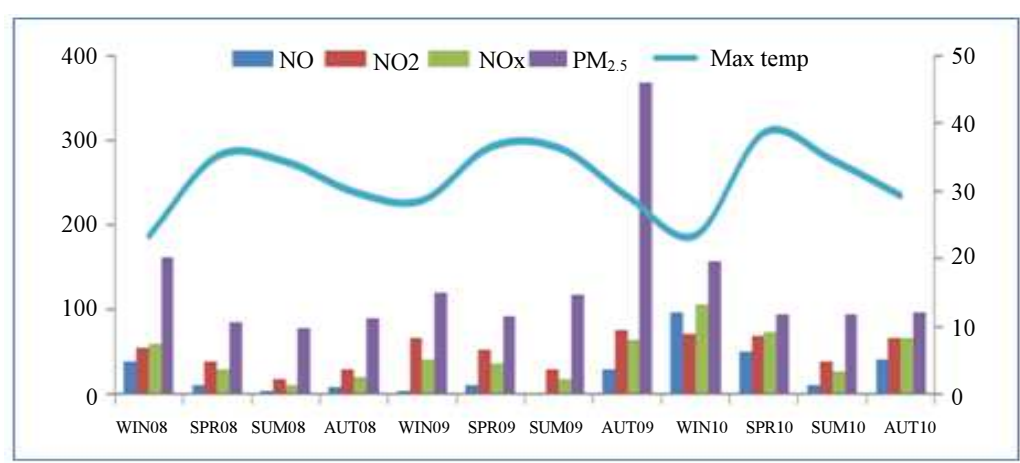

(a)

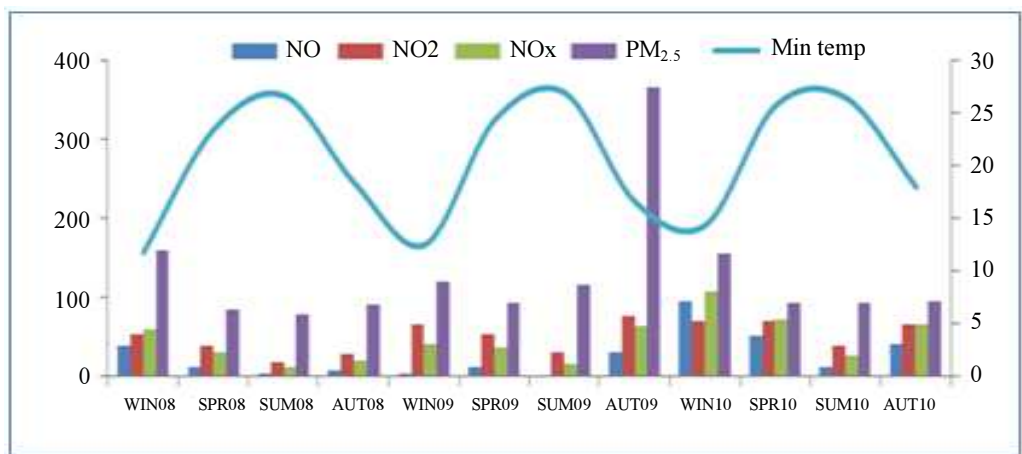

(b)

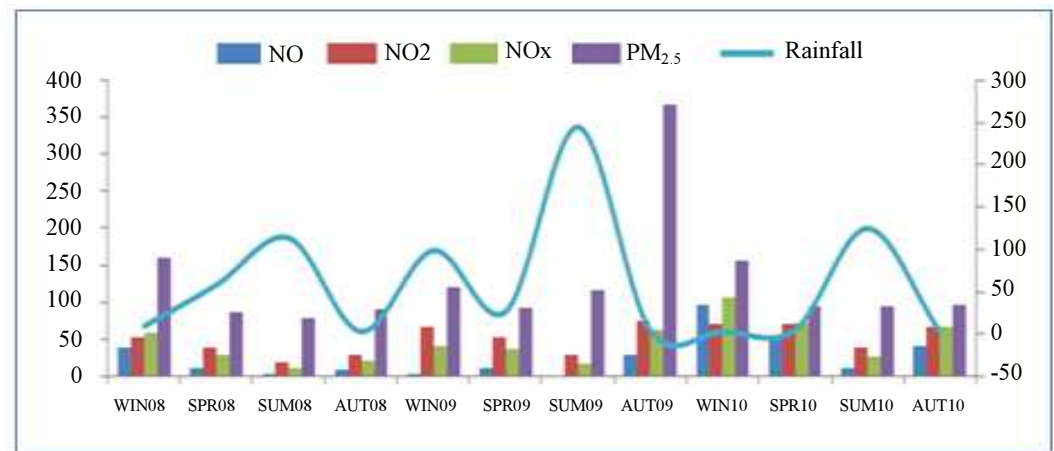

(c)

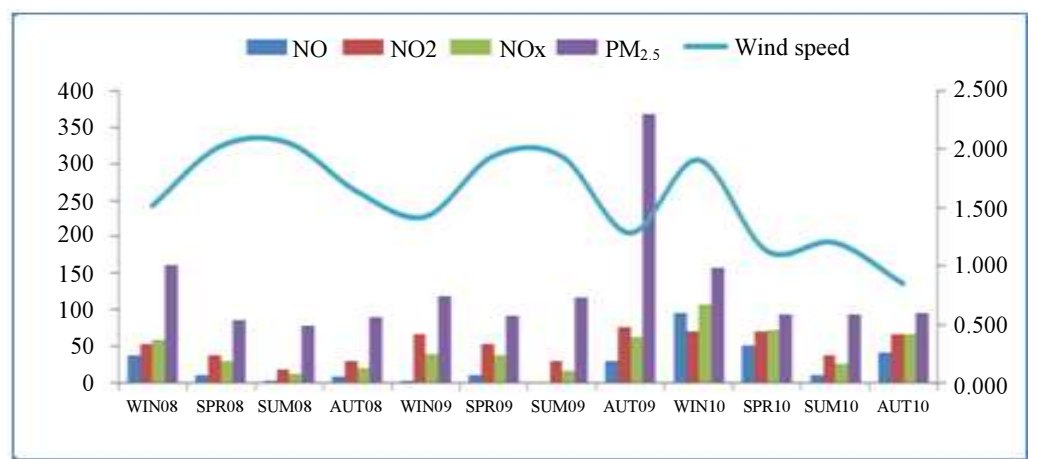

(d)

Fig. 4: Seasonal mean variation of emissions with a) Maximum Temp $\left({ }^{\circ} \mathrm{C}\right)$ b) Minimum Temp $\left({ }^{\circ} \mathrm{C}\right)$ c) Rainfall $(\mathrm{mm})$ and d) Wind Speed $(\mathrm{m} / \mathrm{s})$ for Lahore City 


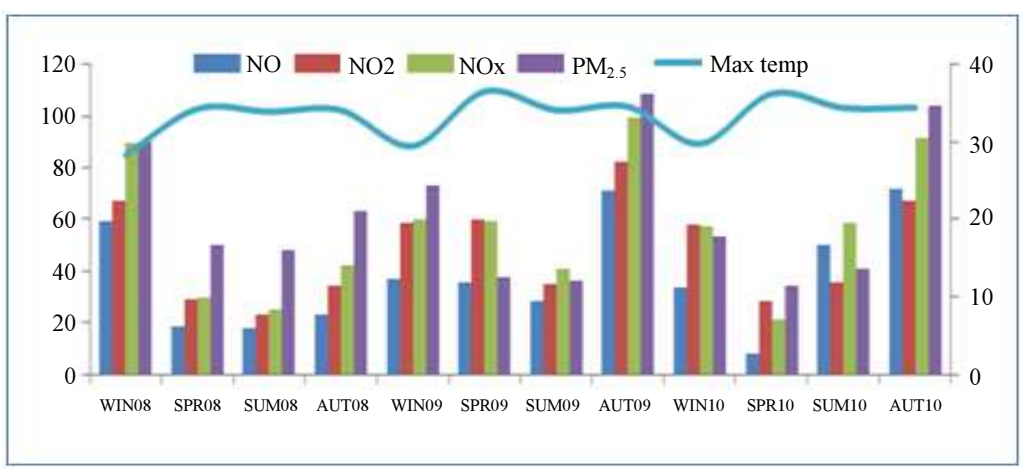

(a)

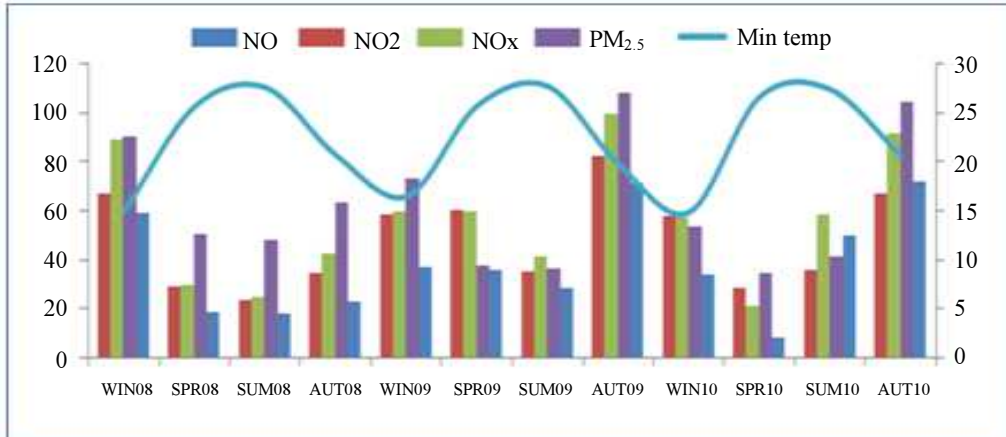

(b)

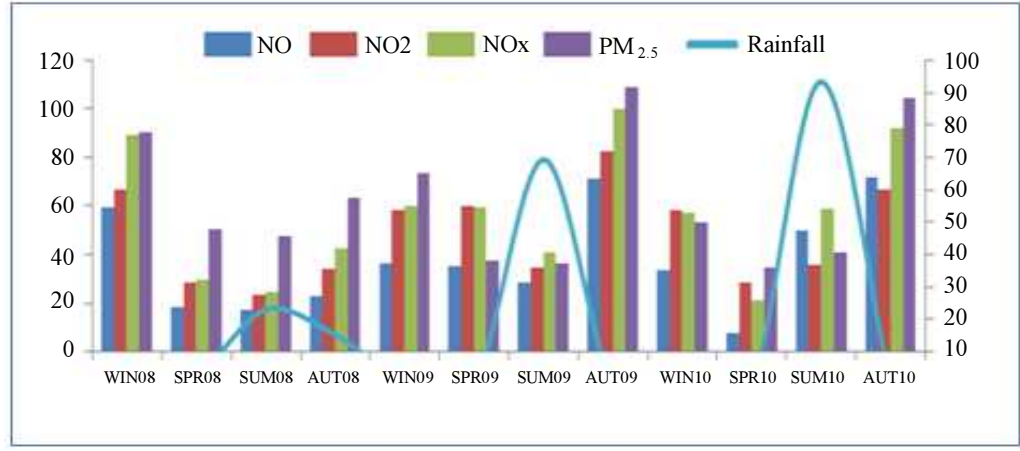

(c)

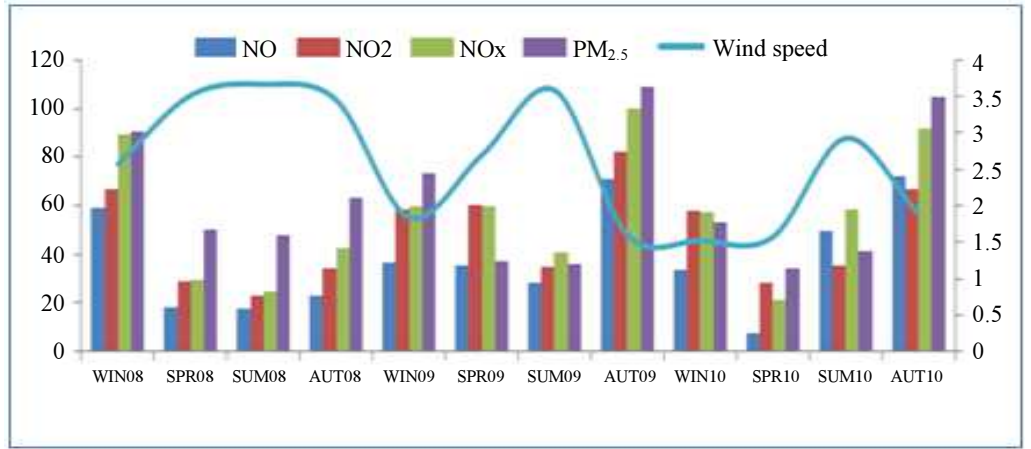

(d)

Fig. 5: Seasonal mean variation of emissions with a) Maximum Temp $\left({ }^{\circ} \mathrm{C}\right)$ b) Minimum Temp $\left({ }^{\circ} \mathrm{C}\right)$ c) Rainfall $(\mathrm{mm})$ and d) Wind Speed (m/s) for Karachi City 
In autumn season 2009, the concentration of $\mathrm{NO}_{\mathrm{x}}$ and $\mathrm{PM}_{2.5}$ with values of $99.65 \mathrm{ppb}$ and $108.5 \mathrm{ug} / \mathrm{m}^{3}$ were highest as compared to other years. Pak-EPA ambient quality standards for $\mathrm{NO}_{\mathrm{x}}$ and $\mathrm{PM}_{2.5}$ were $40 \mathrm{ug} / \mathrm{m}^{3}$ and $25 \mathrm{ug} / \mathrm{m}^{3}$ that were quite high, compared to permissible limits. Same trend was observed with minimum temperature. Generally, it was noted that highest level of emissions concentration was observed in the autumn season (Adeeb, 2014) (Fig. 5a and b). Maximum rainfall was experienced in summer season in 2010, i.e., 93.2 (mm), but at the same time, the lowest level of emissions was recorded (Fig. 5c).

It was found out that meteorological factors such as rainfall and relative humidity had significant negative impacts on emission concentrations in the city (Bhaskar et al., 2008; Xie et al., 2018). In contrast, temperature and wind speed showed positive correlation with the pollution load dispersion. In Winter 2008 as the wind speed increased the level of pollutants also increased. Maximum level of emissions were recorded in autumn 2009 with a wind speed of $3.58 \mathrm{~m} / \mathrm{sec}$ (Fig. $5 \mathrm{~d}$ )

Correlation analyses were carried out to quantify the relationship, between the meteorological and pollution variables as shown in Table 2 . In all cities, there is a negative correlation of both maximum and minimum temperature that has been observed. The reason behind the negative correlation is that high temperatures enhance convection currents, which helps in good air mixing and reducing emissions specially $\mathrm{PM}_{2.5}$ concentrations. Lower air temperatures cause the stable atmosphere, hence, result in the poor air quality (Lepeule et al., 2018). Wind speed showed a positive correlation with emissions concentrations (Table 2). As wind blows it distributes the exhaust gases from the industries into metropolitan area that mainly includes $\mathrm{NO}, \mathrm{NO}_{\mathrm{X}}, \mathrm{PM}_{2.5}$, which poses detrimental impacts in human health (Di et al., 2017b). Similarly, rainfall showed negative correlation as it removes the pollutants from the atmosphere. Usually, Karachi experience less precipitation due to inversion layer that traps the contaminants during winter season. In winter season Islamabad is more polluted because winter smog is caused when a mixture of pollutants builds up at ground level and layer of cold air traps the warm air containing pollutants and elevates the levels (Amato et al., 2014; Deng et al., 2018).

Annual mean concentration and their relative percentage of pollutants were also calculated (Table 3 ). The highest average mean counts were recorded in Lahore with a value of $238.16 \mathrm{ug} / \mathrm{m}^{3}$ followed by Islamabad $\left(256.0 \mathrm{ug} / \mathrm{m}^{3}\right)$ and Karachi $\left(53.28 \mathrm{ug} / \mathrm{m}^{3}\right)$. In Lahore and Karachi, $\mathrm{PM}_{2.5}$ showed its major contribution with an average of $119.2 \mathrm{ug} / \mathrm{m}^{3}$ and its percentage contribution $(91.69 \%),\left(65.13 \mathrm{ug} / \mathrm{m}^{3}, 87.97 \%\right)$ to the total atmosphere whereas in Islamabad $\mathrm{NO}_{\mathrm{x}}$ contributes $57.68 \%$ respectively (Table 3 ). If we compare ambient air quality situation among three cities, Lahore is the most polluted one followed by Islamabad and Karachi. The main reason is that the vehicular emissions have been dominated by emissions from old and poorly maintained vehicles that contribute to enhanced ambient concentrations of fine particulates (Deng et al., 2018; Lodhi, 2006). Anthropogenic sources contributed for about $15 \%$ of the total hydrocarbon emissions in the atmosphere. The gases acted like a blanket where ever their concentration increased. However, local heat and increased differences between hotter and colder regions were reported as driving factors (Ahmed et al., 2014; Li et al., 2018).

Table 2: Correlation coefficients of air emissions and meteorological parameters for the years 2008-2010

\begin{tabular}{|c|c|c|c|c|c|c|c|c|c|c|}
\hline \multirow[b]{2}{*}{ Emissions } & \multirow[b]{2}{*}{ Met parameters } & \multicolumn{3}{|l|}{2008} & \multicolumn{3}{|l|}{2009} & \multicolumn{3}{|l|}{2010} \\
\hline & & $\begin{array}{l}\text { ISL } \\
\mathrm{R}\end{array}$ & $\begin{array}{l}\text { LHR } \\
\mathrm{R}\end{array}$ & $\begin{array}{l}\text { KHI } \\
\mathrm{R}\end{array}$ & $\begin{array}{l}\text { ISL } \\
\mathrm{R}\end{array}$ & $\begin{array}{l}\text { LHR } \\
\mathrm{R}\end{array}$ & $\begin{array}{l}\text { KHI } \\
\text { R }\end{array}$ & $\begin{array}{l}\text { ISL } \\
\mathrm{R}\end{array}$ & $\begin{array}{l}\text { LHR } \\
\mathrm{R}\end{array}$ & $\begin{array}{l}\text { KHI } \\
\text { R }\end{array}$ \\
\hline \multirow[t]{4}{*}{$\overline{\mathrm{NO}\left(\mu \mathrm{g} / \mathrm{m}^{3}\right)}$} & Max temp $\left({ }^{\circ} \mathrm{C}\right)$ & -0.51 & -0.79 & -0.84 & -0.70 & -0.34 & 0.10 & -0.83 & -0.56 & -0.13 \\
\hline & Min Temp $\left({ }^{\circ} \mathrm{C}\right)$ & -0.64 & -0.81 & -0.94 & -0.83 & -0.22 & -0.35 & -0.96 & -0.72 & -0.17 \\
\hline & Wind Speed $(\mathrm{m} / \mathrm{s})$ & 0.49 & 0.70 & 0.71 & 0.62 & 0.53 & 0.54 & 0.52 & 0.49 & 0.54 \\
\hline & Rainfall (mm) & -0.58 & -0.43 & -0.23 & -0.55 & -0.53 & -0.22 & -0.77 & -0.37 & 0.04 \\
\hline \multirow[t]{4}{*}{$\mathrm{NO}_{2}\left(\mu \mathrm{g} / \mathrm{m}^{3}\right)$} & Max temp $\left({ }^{\circ} \mathrm{C}\right)$ & -0.32 & -0.70 & -0.65 & -0.60 & -0.41 & -0.15 & -0.74 & -0.35 & -0.63 \\
\hline & Min Temp $\left({ }^{\circ} \mathrm{C}\right)$ & -0.44 & -0.83 & -0.91 & -0.73 & -0.79 & -0.64 & -0.91 & -0.57 & -0.78 \\
\hline & Wind Speed $(\mathrm{m} / \mathrm{s})$ & 0.68 & 0.71 & 0.57 & 0.58 & 0.71 & 0.76 & 0.46 & 0.51 & 0.76 \\
\hline & Rainfall (mm) & -0.46 & -0.60 & -0.31 & -0.62 & -0.67 & -0.38 & -0.73 & -0.44 & -0.44 \\
\hline \multirow[t]{4}{*}{$\mathrm{NO}_{\mathrm{x}}(\mathrm{ppb})$} & Max temp $\left({ }^{\circ} \mathrm{C}\right)$ & -0.49 & -0.79 & -0.68 & -0.72 & -0.50 & 0.00 & -0.82 & -0.55 & -0.29 \\
\hline & Min Temp $\left({ }^{\circ} \mathrm{C}\right)$ & -0.61 & -0.85 & -0.90 & -0.84 & -0.64 & -0.48 & -0.96 & -0.71 & -0.37 \\
\hline & Wind Speed $(\mathrm{m} / \mathrm{s})$ & -0.53 & -0.74 & -0.49 & 0.64 & -0.74 & -0.65 & -0.53 & -0.55 & -0.65 \\
\hline & Rainfall (mm) & -0.56 & -0.51 & -0.24 & -0.57 & -0.70 & -0.29 & -0.78 & -0.39 & -0.10 \\
\hline \multirow[t]{4}{*}{$\mathrm{PM}_{2.5}\left(\mu \mathrm{g} / \mathrm{m}^{3}\right)$} & Max temp $\left({ }^{\circ} \mathrm{C}\right)$ & -0.30 & -0.60 & -0.22 & -0.74 & -0.44 & -0.47 & -0.91 & -0.81 & -0.63 \\
\hline & Min Temp $\left({ }^{\circ} \mathrm{C}\right)$ & -0.43 & -0.68 & -0.50 & -0.83 & -0.42 & -0.77 & -0.94 & -0.90 & -0.71 \\
\hline & Wind Speed $(\mathrm{m} / \mathrm{s})$ & 0.33 & 0.47 & 0.47 & 0.29 & 0.45 & 0.74 & 0.54 & 0.57 & 0.74 \\
\hline & Rainfall (mm) & -0.67 & -0.60 & -0.27 & -0.50 & -0.22 & -0.28 & -0.60 & -0.30 & -0.39 \\
\hline
\end{tabular}


Table 3: Annual mean concentration and relative percentage of each of pollutant type in the atmosphere of Islamabad, Lahore and Karachi, Pakistan

\begin{tabular}{|c|c|c|c|c|c|c|}
\hline \multirow{2}{*}{$\frac{\text { Emissions }}{\text { Islamabad }}$} & \multicolumn{3}{|c|}{ Yearly mean count } & \multicolumn{3}{|c|}{ \%age contribution to total atmosphere } \\
\hline & $2008-2009$ & $2009-2010$ & Average & $2008-2009$ & $2009-2010$ & Average \\
\hline $\mathrm{NO}\left(\mu \mathrm{g} / \mathrm{m}^{3}\right)$ & 65.21 & 73.44 & 69.33 & 26.08 & 28.02 & 52.42 \\
\hline $\mathrm{NO} 2\left(\mu \mathrm{g} / \mathrm{m}^{3}\right)$ & 45.24 & 45.02 & 45.13 & 18.09 & 17.62 & 34.22 \\
\hline NOx (ppb) & 72.49 & 80.07 & 76.28 & 28.99 & 30.55 & 57.68 \\
\hline PM2.5 $\left(\mu \mathrm{g} / \mathrm{m}^{3}\right)$ & 67.14 & 63.56 & 65.35 & 26.85 & 24.25 & 49.43 \\
\hline Total & 250.09 & 262.09 & 256.09 & & & \\
\hline \multicolumn{7}{|l|}{ Lahore } \\
\hline $\mathrm{NO}\left(\mu \mathrm{g} / \mathrm{m}^{3}\right)$ & 14.48 & 30.26 & 22.37 & 6.56 & 11.82 & 17.10 \\
\hline $\mathrm{NO} 2\left(\mu \mathrm{g} / \mathrm{m}^{3}\right)$ & 47.41 & 56.94 & 52.18 & 21.5 & 22.25 & 40.06 \\
\hline $\mathrm{NO}_{\mathrm{x}}(\mathrm{ppb})$ & 36.49 & 52.32 & 44.40 & 16.55 & 20.44 & 34.04 \\
\hline PM $2.5\left(\mu \mathrm{g} / \mathrm{m}^{3}\right)$ & 122.05 & 116.37 & 119.21 & 55.36 & 45.47 & 91.69 \\
\hline Total & 220.43 & 255.89 & 238.16 & & & \\
\hline \multicolumn{7}{|l|}{ Karachi } \\
\hline $\mathrm{NO}\left(\mu \mathrm{g} / \mathrm{m}^{3}\right)$ & 37.11 & 40.33 & 38.72 & 69.92 & 75.38 & 52.29 \\
\hline $\mathrm{NO} 2\left(\mu \mathrm{g} / \mathrm{m}^{3}\right)$ & 50.03 & 50.99 & 50.51 & 94.27 & 95.30 & 68.22 \\
\hline $\mathrm{NO}_{\mathrm{x}}(\mathrm{ppb})$ & 58.79 & 58.77 & 58.78 & 110.77 & 109.85 & 79.39 \\
\hline PM $2.5\left(\mu \mathrm{g} / \mathrm{m}^{3}\right)$ & 66.36 & 63.90 & 65.13 & 125.04 & 119.43 & 87.97 \\
\hline Total & 53.07 & 53.50 & 53.28 & & & \\
\hline
\end{tabular}

\section{Conclusion}

The study conducted in three major metropolitan cities (Islamabad, Lahore and Karachi) of Pakistan showed annual and seasonal variability of atmospheric emissions from 2008-2010. The four different types of pollutants $\left(\mathrm{NO}, \mathrm{NO}_{2}, \mathrm{NO}_{\mathrm{x}}, \mathrm{PM}_{2.5}\right)$ were analyzed, out of which, $\mathrm{PM}_{2.5}$ was the most significant. The meteorological conditions such as temperature and rainfall depicted a negative correlation with emissions whereas wind speed showed a positive correlation. The annual mean concentration of $\mathrm{PM}_{2.5}$ was found highest in Lahore. The maximum concentrations of emissions $\left(\mathrm{NO}, \mathrm{NO}_{2}, \mathrm{NO}_{\mathrm{x}}, \mathrm{PM}_{2.5}\right.$ ) were observed in all cities during winter. The comparison among the cities based on statistical analysis revealed Lahore as the most polluted city, compared to Karachi and Islamabad. Finally, it could be considered that the atmospheric pollution comes from anthropogenic activities in urban area and is predominantly due to auto-vehicular traffic. The level of air pollution in the Pakistan's two largest cities, Karachi and Lahore are estimated to be 20 times higher than World Health Organization standards and is continuously rising. The increased number of vehicles, use of low-quality fuel and industrial activities are the significant driving forces of air pollution. There fore, an efficient mass transit system and control of industrial emission would help to cope with current emissions and future worse scenarios.

\section{Acknowledgment}

The authors are sincerely grateful for the supports from the CAS Team Project of the Belt and Road (to D.S.P.), the Three Hundred Leading Talents in Scientific and Technological Innovation Program of Chongqing (No. CSTCCXLJRC201714) and the University of Chinese Academy of Sciences (UCAS) for CAS-TWAS Scholarship (No. 2017A8018537001 to N.H).

\section{Author's Contributions}

Naima Hamid: Extracted, analyzed the data and wrote the first draft.

Muhammad Junaid and Syeda Maria Ali: Develop illustration, analyze and revise the paper.

Maida Zahid: Assisted to assemble the meteorological data from Pakistan Meteorological Department.

De-Sheng Pei: Conceived, designed and revised the paper.

\section{Ethics}

All the primary data acquired were in agreement from the Pakistan Metrological Department (PMD), Research and Development Division, Islamabad, Pakistan.

\section{References}

Adeeb, F., 2014. A snapshot of winter air pollution in Quetta, Balochistan, Pakistan. Air Quality Climate Change, 48: 24-30.

Ahmed, D., A. Zubair, A. Begum and M.U. Khan, 2014. Investigation and evaluation of ambient air quality in various parts of Karachi metropolitan city, Pakistan. Middle-East J. Sci. Res., 21: 234-243.

Ali, M. and M. Athar, 2010. Impact of transport and industrial emissions on the ambient air quality of Lahore city, Pakistan. Environ. Monit. Assess., 171: 353-363. DOI: 10.1007/s10661-009-1283-0 
Amato, D.G., K.C. Bergmann, L. Cecchi, I. AnnesiMaesano and D.M. Amato et al., 2014. Climate change and air pollution. Allergo J., 23: 32-38. DOI: 10.1007/S15007-014-0484-1

Aunan, K. and X.C. Pan, 2004. Exposure-response functions for health effects of ambient air pollution applicable for China-a meta-analysis. Sci. Total Environ., 329: 3-16. DOI: $10.1016 /$ j.scitotenv.2004.03.008

Bhaskar, B.V., R.V.J. Rajasekhar, P. Muthusubramanian and A.P. Kesarkar, 2008. Measurement and modelling of respirable particulate (PM10) and lead pollution over Madurai, India. Air Qual. Atmos. Health, 1: 45-55. DOI: 10.1007/S1 1869-008-0004-0

Cai, Y., A.L. Hansell, M. Blangiardo, P.R. Burton and S. Hodgson et al., 2017. Long-term exposure to road traffic noise, ambient air pollution and cardiovascular risk factors in the HUNT and lifelines cohorts. Eur. Heart J., 38: 2290-2296. DOI: 10.1093/EURHEARTJ/EHX263

Chen, K., K. Wolf, S. Breitner, A. Gasparrini and A. Schneider et al., 2018. Two-way effect modifications of air pollution and air temperature on total natural and cardiovascular mortality in eight European urban areas. Environ. Int., 116: 186-196. DOI: 10.1016/J.ENVINT.2018.04.021

Christodoulakis, J., C.A. Varotsos, A.P. Cracknell and G.A. Kouremadas, 2018. The deterioration of materials as a result of air pollution as derived from satellite and ground based observations. Atmospheric Environ., 185: 91-99.

DOI: 10.1016/J.ATMOSENV.2018.04.052

Deng, X., W. Cao, Y. Huo, G. Yang and X. Zhao et al., 2018. Meteorological conditions during a severe, prolonged regional heavy air pollution episode in eastern China from December 2016 to January 2017. Theoretical Applied Climatology.

Dentener, F., D. Stevenson, K. Ellingsen, N.T. Van and M. Schultz et al., 2006. The global atmospheric environment for the next generation. Environ. Sci. Technol., 40: 3586-94. DOI: 10.1021/ES0523845

Derwent, R.G. and O. Hertel, 1998. Transformation of Air Pollutants. In: Urban Air Pollution European Aspects, Environmental Pollution. Fenger, J., O. Hertel and F. Palmgren (Eds.), Dordrecht, Boston, 137-159. DOI: 10.1007/978-94-015-9080-8_8

Di, Q., L. Dai, Y. Wang, A. Zanobetti and F. Dominici et al., 2017a. Association of short-term exposure to air pollution with mortality in older adults. Jama, 318 : 2446-2456. DOI: 10.1001/JAMA.2017.17923

Di, Q., L. Dai, Y. Wang, A. Zanobetti and F. Dominici et al., 2017b. Air pollution and mortality in the medicare population. N. Engl. J. Med., 376: 2513-2522.

DOI: $10.1056 /$ NEJMOA1702747
Dotse, S.Q., L. Dagar, M.I. Petra and S.L.C. De, 2016. Evaluation of national emissions inventories of anthropogenic air pollutants for Brunei Darussalam. Atmospheric Environ., 133: 81-92. DOI: 10.1016/J.ATMOSENV.2016.03.024

Espinosa, A.J.F., M.T. Rodriguez and F.F. Alvarez, 2004. Source characterization of fine urban particles by multivariate analysis of trace metal speciation. Atmos. Environ., 38: 873-886. DOI: 10.1016/J.ATMOSENV.2003.10.046

Guo, P., Y. Wang, W. Feng, J. Wu and H. Liu et al., 2017. Ambient air pollution and risk for ischemic stroke: A short-term exposure assessment in South China. Int. J. Environ. Res. Public Health, 14: E1091. DOI: 10.3390/IJERPH14091091

Guo, Y.L., L. Ying-Chu, F.C. Sung, S.L. Huang and D.W. Dockery et al., 1999. Climate, traffic-related air pollutants and asthma prevalence in middle-school children in taiwan. Environ. Health Perspectives 107: 1001-1006. DOI: 10.1289/EHP.991071001

Hou, P. and S. Wu, 2016. Long-term changes in extreme air pollution meteorology and the implications for air quality. Sci. Rep., 6: 23792. DOI: 10.1038/SREP23792

Ilyas, S.Z., A.I. Khattak, S.M. Nasir, T. Qurashi and R. Durrani, 2010. Air pollution assessment in urban areas and its impact on human health in the city of Quetta, Pakistan. Clean Technol. Environ. Policy, 12: 291-299. DOI: 10.1007/S10098-009-0209-4

Karar, K., A.K. Gupta, A. Kumar, A.K. Biswas and S. Devotta, 2005. Statistical Interpretation of week day/week end differences of ambient gaseous pollutant, vehicular traffic and meteorological parameter in urban region of Kolkatta. J. Environ. Sci. Eng., 47: 164.175.

Kartal, S.O.U., 1998. Determination and parameterization of some air pollutants as a function of meteorological parameters in Kayseri, Turkey. Air Waste Management Associat., 48: 853-859. DOI: 10.1080/10473289.1998.10463738

Katsouyanni, K., A. Pantazopoulou, G. Touloumi, I. Tselepidaki and D. Trichopoulos, 1993. Evidence for interaction between air pollution and high temperature in the causation of excess mortality. Archives Environ. Health: Int. J., 48: 235-242. DOI: 10.1080/00039896.1993.9940365

Khreis, H., C. Kelly, J. Tate, R. Parslow and M. Nieuwenhuijsen, 2017. Exposure to traffic-related air pollution and risk of development of childhood asthma: A systematic review and metaanalysis. Environ. Int., 100: 1-31.

DOI: 10.1016/J.ENVINT.2016.11.012

Lepeule, J., A.A. Litonjua, A. Gasparrini, P. Koutrakis and J. Schwartz, 2018. Lung function association with outdoor temperature and relative humidity and its interaction with air pollution in the elderly. Environ. Res., 165: 110-117. DOI: 10.1016/J.ENVRES.2018.03.039 
Li, C., Z. Bai, S. Kong, B. Han and A. Liu et al., 2010. A land use regression for predicting $\mathrm{NO} 2$ and PM10 concentrations in different seasons in Tianjin region, China. J. Environ. Sci., 22: 1364-1373. DOI: 10.1016/S1001-0742(09)60263-1

Li, D., J.B. Wang, Z.Y. Zhang, P. Shen and K. Chen et al., 2018. Association between short-term exposure to ambient air pollution and daily mortality: A time-series study in Eastern China. Environ. Sci. Pollut. Res. Int., 25: 16135-16143. DOI: 10.1007/S11356-018-1759-Y

Liu, H., B. Wu, S. Liu, P. Shao and H. Tian et al., 2018. A regional high-resolution emission inventory of primary air pollutants in 2012 for Beijing and the surrounding five provinces of North China. Atmospheric Environ., 181: 20-33. DOI: 10.1016/J.ATMOSENV.2018.03.013

Lodhi, Z., 2006. Ambient air quality in Pakistan. http://www.environment.gov.pk/PRO_PDF/Ambien tAirQtyPakistan.pdf

McCarroll, J. and W. Bradley, 1996. Excess Mortality as an Indicator of Health Effects of Air Pollution. Am. J. Public Health, 56: 1933-1942. DOI: $10.2105 /$ AJPH.56.11.1933

Parekh, P.P., H.A. Khwaja, A.R. Khan, R.R. Naqvi and A, Malik et al., 2001. Ambient air quality of two metropolitan cities of Pakistan and its health implications. Atmospheric Environ., 35: 5971-5978. DOI; 10.1016/S1352-2310(00)00569-0

Qiu, H., K. Tan, F. Long, L. Wang and J. Pan et al., 2018. The burden of COPD morbidity attributable to the interaction between ambient air pollution and temperature in Chengdu, China. Int. J. Environ. Res. Public Health, 15: 492. DOI: 10.3390/IJERPH15030492

Shahid, I., M. Kistler, A. Mukhtar, B.M. Ghauri and H. Puxbaum et al., 2016. Chemical characterization and mass closure of PM10 and PM2.5 at an urban site in Karachi-Pakistan. Atmospheric Environ., 128: 114-123.

DOI: 10.1016/J.ATMOSENV.2015.12.005

Srivastava, R.R., 2006. Air quality index: A brief review. Indian J. Environ. Prot., 26: 344-347

Stern, 1976. ACAPV. 1st Edn., New York, USA.
Vedrenne, M., R. Borge, J. Lumbreras, M.E. Rodríguez and C. Quaassdorff et al., 2016. A comprehensive approach for the evaluation and comparison of emission inventories in Madrid. Atmospheric Environ., 145: 29-44. DOI: 10.1016/J.ATMOSENV.2016.09.020

WHO/UNEP, 1992. Urban Air Pollution in Mega-cities of the World. World Health Organization/United Nations Environment Programme, Blackwell, Oxford.

Wing, J.J., S.D. Adar, B.N. Sanchez, L.B. Morgenstern and L.D. Lisabeth et al., 2017. Short-term exposures to ambient air pollution and risk of recurrent ischemic stroke. Environ., Res. 152: 304-307. DOI: 10.1016/J.ENVRES.2016.11.001

Xie, N., L. Zou and L. Ye, 2018. The effect of meteorological conditions and air pollution on the occurrence of type A and B acute aortic dissections. Int. J. Biometeorol., 62: 1607-1613. DOI: $10.1007 / \mathrm{S} 00484-018-1560-0$

Yang, Y., H. Liao and S. Lou, 2015. Decadal trend and interannual variation of outflow of aerosols from East Asia: Roles of variations in meteorological parameters and emissions. Atmospheric Environ., 100: $141-153$.

DOI: 10.1016/J.ATMOSENV.2014.11.004

Zawacki, M., K.R. Baker, S. Phillips, K. Davidson and P. Wolfe, 2018. Mobile source contributions to ambient ozone and particulate matter in 2025. Atmospheric Environ., 188: 129-141. DOI: 10.1016/J.ATMOSENV.2018.04.057

Zhang, R.J., Z.X. Shen, H. Zou, W. Wang and J. Zhou et al., 2008. Study of elemental mass size distributions of aerosol in lijiang, a background site in Southwest China. Aerosol Air Qual. Res., 8: 339-347. DOI: 10.4209/AAQR.2008.06.0022

Zhao, L., C. Chen, P. Wang, Z. Chen and B. Lu et al., 2015. Influence of atmospheric fine particulate matter (PM2.5) pollution on indoor environment during winter in Beijing. Build. Environ., 87: 283-291.

DOI: $10.1016 /$ J.BUILDENV.2015.02.008

Zhao, Y. and D. Shi, 2012. Analysis of total suspended particulates pollution along shanghai nanjing express way. Open J. Air Pollut., 1: 31-36.

\section{Highlights:}

- $\quad$ Air quality trend was monitored in metropolitan cities of Pakistan (Karachi, Lahore, and Islamabad)

- Among all primary pollutants, $\mathrm{PM}_{2.5}$ was the highest levels in all the cities

- Pollutants are positively correlated with wind speed and negatively correlated with temperature and rainfall

- Elevated pollution levels were observed in Lahore followed by Karachi and Islamabad

- The highest annual and seasonal variation in Karachi could be attributed to the inversion process

\section{Graphical Abstract}




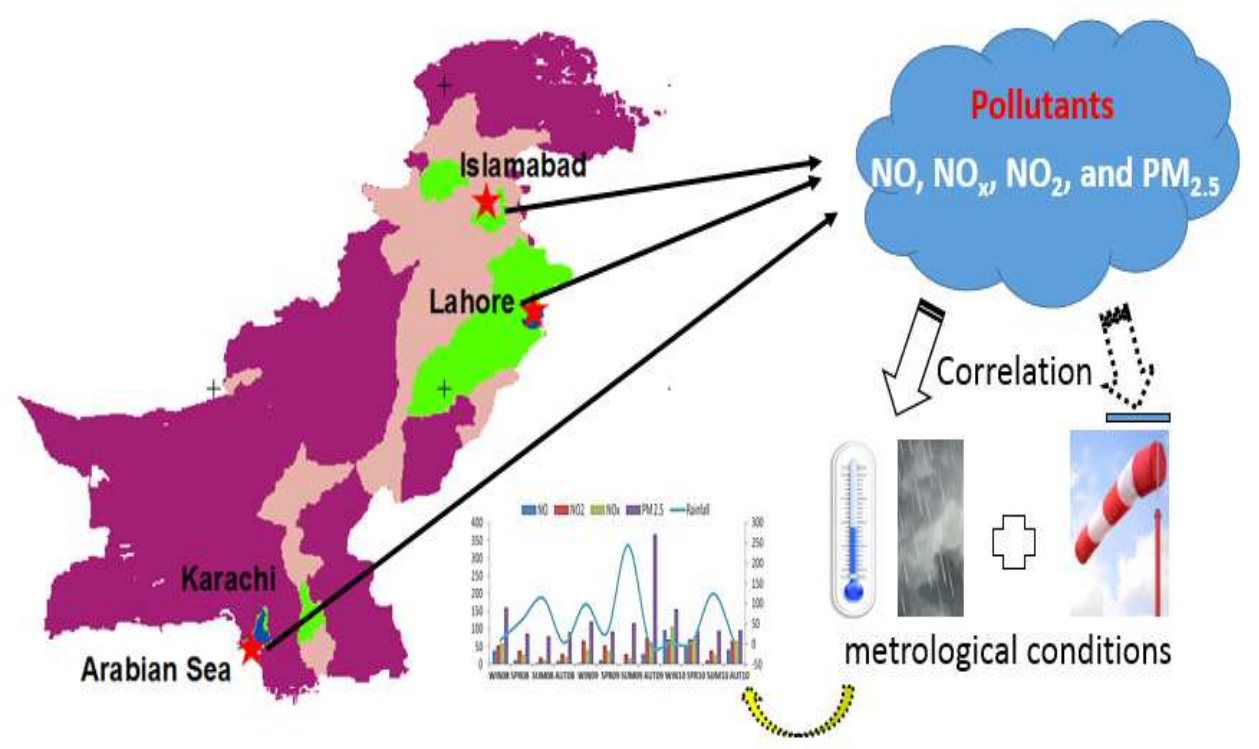

